\title{
PENGARUH MODEL PEMBELAJARAN GROUP INVESTIGATION TERHADAP HASIL BELAJAR DITINJAU DARI GAYA BELAJAR SISWA KELAS XI IPS
}

\author{
Khusnul Khuluq, Zainal Abidin, Saida Ulfa \\ Jurusan Teknologi Pendidikan, Fakultas Ilmu Pendidikan, Universitas Negeri Malang \\ Jalan Semarang 5 Malang 65145 0341-574700 \\ khuluqkhusnul89@gmail.com
}

\section{Article History}

Received: 28 Oktober 2020, Accepted: 23 Desember 2020, Published: 28 Mei 2021

\begin{abstract}
Abstrak
Penelitian ini digunakan untuk mengukur adanya perbedaan antara kelas yang menggunakan metode pembelajaran klasikal dengan kelas yang menggunakan metode pembelajaran Group Investigation (GI) pada siswa kelas XI IPS di SMAN 9 Malang. Pelaksanaan pembelajaran ini dilakukan secara daring dan penyebaran angket serta tes pebelajar mengisi pada google form. Penelitian ini melibatkan dua kelas yakni kelas kontrol dan kelas eksperimen. Pengujian data menggunakan uji validitas dan uji reliabilitas. Uji berikutnya yaitu menggunakan uji tingkat kesukaran soal dan uji daya pembeda soal. Dari penelitian ini diperoleh hasil adanya pengaruh model pembelajaran GI terhadap hasil belajar siswa yang ditunjukkan oleh adanya perubahan hasil belajar siswa. Kemudian ditemukan pengaruh gaya belajar terhadap gaya belajar siswa yang ditunjukkan adanya perbedaan hasil belajar siswa pada tiap gaya belajar. Yang terakhir adanya interaksi model pembelajaran GI terhadap hasil belajar ditinjau dari gaya belajar siswa yang dibuktikan oleh adanya perbedaan hasil belajar siswa pada tiap kategori gaya belajar.
\end{abstract}

Keyword: Model pembelajaran; Group Investigation; Hasil belajar;

\begin{abstract}
This research was used to measure the difference between classes that use classical learning methods and classes that use Group Investigation learning methods in grade XI IPS students in SMAN 9 Malang. The implementation of this learning is carried out online and the distribution of questionnaires and student tests to fill in the google form. This study involved two classes, namely the controller class and the experimental class. Testing data using validity and reliability tests. The next test is to use the problem level test and the distinguishing power test. From this study, it was found that the influence of the GI learning model on student learning outcomes was indicated by changes in student learning outcomes. Then found the influence of learning styles on student learning styles which indicated the difference in student learning outcomes in each learning style. Finally, there is the interaction of the GI learning model with learning outcomes in terms of student learning styles as evidenced by the differences in student learning outcomes in each learning style category.
\end{abstract}

Keyword: Put 3-5 your keywords here in Bahasa Indonesia; keywords separated by semicolon 


\section{PENDAHULUAN}

Peranan seorang Teknolog Pendidikan sangat dibutuhkan karena fungsinya itu sendiri adalah sebagai pemecah masalah pendidikan yang memanfaatkan teknologi yang ada. Makna dari teknologi disini bukan hanya berarti sebuah media atau alat, tetapi juga bisa berupa sebuah pemikiran atau ide untuk menemukan inovasi dalam dunia pendidikan. Teknologi pendidikan mempunyai lima kawasan yakni; desain, pengembangan, pemanfaatan, pengelolaan, dan evaluasi. Masalah dalam kelas ketika proses pembelajaran dapat diatasi dengan cara memilih model pembelajaran yang tepat dan tidak membosankan bagi pebelajar. Untuk melaksanakannya diperlukan pembaruan dalam model pembelajaran agar siswa tidak bosan ketika belajar. Pada perkembangan zaman yang modern seperti saat ini, sebagai seorang pendidik (guru) harus lebih cermat dan selektif dalam memilih model pembelajaran yang dipraktekkan di dalam kelas (Oktaviansa \& Yunus, 2013). Apabila pendidik menggunakan strategi yang kurang tepat atau kurang cocok maka menyangkut pada hasil yang kurang memuaskan atau optimal (Gunawan et al., 2017). Peranan bagi guru ini sangat penting dalam penentuan model pembelajaran yakni bisa dengan cara memfasilitasi serta menambah pengalaman belajarnya (Ahrisya, 2019). Dalam pemilihan model pembelajaran yang cocok nan strategis maka seorang pendidik perlu melihat kemampuan pebelajar untuk menghasilkan model belajar yang serasi dengan kriteria masing-masing pebelajar. Strategi pembelajaran yang kondusif dan baik harus diperhitungkan semua kondisi pebelajar baik dalam keadaan internal maupun eksternal.

Model pembelajaran Group Investigation (GI) merupakan model pembelajaran kooperatif yang mengharuskan pebelajar untuk aktif dan ikut serta dalam proses pembelajaran (Slavin, 2010) dengan menggali informasi materi yang dipelajari secara mandiri baik melalui buku bacaan atau mencarinya secara daring (Wicaksono, 2017). Pada pembelajaran GI pebelajar yang dilibatkan sejak awal dalam memastikan topik ataupun untuk pembelajaran secara investigasi mendorong pebelajar untuk memiliki keahlian berkomunikasi dengan baik, karena dalam kelompok tersebut menekankan keterlibatan dan kegiatan si pebelajar secara mandiri guna mencari topik materi (Arifin dan Afandi, 2015). Menurut Suparmi, et al. (2016) pada pembelajaran koperatif tersebut, pebelajar ditujukan pada proses berpikir teman-temannya, dengan metode GI ini tidak hanya membuat hasil belajarnya transparan untuk pebelajar lainnya, tetapi ini juga membuat proses berpikir pebelajar lain menjadi terbuka untuk seluruh pebelajar atau teman-temannya. Model pembelajaran GI adalah sedikit dari banyaknya bentuk pembelajaran yang berpacu pada keterlibatan serta aktivitas pembelajar guna mencari materi pelajaran yang dipelajari secara mandiri atau bersama-sama lewat bahan yang ada di berbagai media cetak seperti buku maupun digital seperti internet. Dalam hal ini model pernbelajaran GI pebelajar tidak mengandalkan pendidik sebagai sumber belajarnya (Maryani \& Rahayu, (2019). Menurut Rosita (2015) bahwa model GI itu menggunakan sistem berkelompok dengan kondisi kecerdasan yang tak sama. Dengan adanya kerjasama antar teman diharapkan dapat mempermudah pebelajar dalam memahami materi yang diajarkan oleh pendidik dan terjadi interaksi yang bersifat berkelanjutan hingga menambah keeratan antar teman. Model tersebut dipilih agar pebelajar mendapatkan kesempatan untuk berpartisipasi dan aktif dalam menyelesaikan problem yang ditelaah antar individu dalam kelompoknya untuk mengakhiri masalah yang disodorkan pendidik dengan cara kesepakatan antar kelompoknya (Oktaviani, 2018).

Menurut Degeng (1989) bahwa pencapaian hasil belajarnya pebelajar dipengaruhi oleh karakteristik/ciri-ciri pebelajar, seperti minat, keinginan, kemampuan, dan kecenderungan/pilihan perorangan. Serupa dengan paparan sebelumnya Felder (1996) mengutarakan bahwa dalam belajar setiap siswa mempunyai ciri khas dan trik belajar unik nan berbeda dalam cara peserta didik menerima dan memproses informasi. Pendapat lain mengatakan menurut Gunada et al. (2015) dan Purwanto (2005) sama-sama mengatakan hasil belajar itu bisa dilihat apabila terdapat perubahan keterampilan yang diperoleh pebelajar ketika setelah pelaksanaan proses belajar dan pembelajaran. Sedangkan pendapat Wahyuni et al. (2016) hasil belajar bisa juga diartikan sebagai proses perubahan tingkah laku individu karena adanya interaksi sesama individu dan antara dirinya sendiri dengan sekitarnya. 
Seseorang setelah mengalami proses tersebut mengalami transformasi perilaku seperti kecerdasan, keuletan dan sikapnya.

DePorter \& Hernacki (2000) gaya seseorang belajar ialah gabungan dari bagaimana seseorang mendapatkan, kemudian mengolah informasi yang didapatkan. Menurut Pujani (2013) ada tiga jenis gaya berdasarkan pada modalitas yaitu; auditorial, visual, serta yang terakhir kinestetik. Pendapat lain membuktikan jika gaya manusia belajar tidak datang dengan sendirinya melainkan cara yang disukai oleh manusia untuk belajar sesuai dengan kemampuannya (Sternberg, 1994)

Dengan adanya hasil belajar yang dicapai dapat dilihat dari gaya siswa belajar yang diaplikasikan ke dalam model pembelajaran. Model pembelajaran GI dapat dihubungkan dengan gaya siswa belajar apakah sudah sinkron dengan yang diharapkan. Dari paparan sebelumnya didukung oleh Sari (2016) yang mengatakan bahwa penerapan model pembelajaran GI dapat menaikkan hasil belajarnya. Namun hasil tersebut berbeda dengan penelitian yang sudah dilakukan Faujiyah (2017) berbunyi bahwa model GI ini berpengaruh positif kepada hasil belajar pebelajar. Berdasarkan uraian yang dipaparkan tersebut, maka dilakukan penelitian "Pengaruh Model Pembelajaran Group Investigation terhadap Hasil Belajar Siswa ditinjau dari Gaya Belajar Kelas XI SMAN 9 MALANG".

\section{METODE}

Penelitian ini merupakan sebuah penelitian kuantitatif eksperimen semu adalah penelitian yang memiliki perlakuan, pengukuran dampak, unit eksperimen namun tidak menggunakan penugasan secara acak untuk menciptakan perbandingan untuk merumuskan perubahan yang disebabkan adanya perlakuan (Chairunisa, 2017). Terdapat tiga variabel yang diteliti dipenelitian kali ini yaitu variabel model pembelajaran $\left(\mathrm{X}_{1}\right)$, variabel gaya belajar $\left(\mathrm{X}_{2}\right)$, dan variabel hasil belajar $(\mathrm{Y})$. Model penelitian ini dipilih karena model tersebut tidak mengontrol semua variabel luar yang bisa mempengaruhi eksperimen karena hal ini keadaan tidak sanggup untuk mengontrol maupun memanipulasi semua variabel yang relevan. Desain post test digunakan pada penelitian ini guna mengetahui adanya perbedaan hasil belajar siswa di kelas yang menerapkan model investigasi kelompok dan kelas yang menggunakan model klasikal.

Menurut Sugiyono (2001) teknik pengambilan secara random tanpa memperhitungkan pangkat yang ada pada populasi. Populasinya siswa XI IPS SMAN 9 MALANG berjumlah 71 siswa. Dimana kelas XI IPS 1 sejumlah 35 siswa berperan sebagai kelas eksperimen dan kelas XI IPS 2 sejumlah 36 siswa berperan sebagai kelas kontrol. Dari populasi yang sekaligus sebagai sampel penelitian dilakukan analisis melalui uji validitas yaitu untuk memperoleh hasil tingkat kelayakan instrumen dan uji reliabilitas guna mengukur gejala yang serupa di tempat lain. Uji berikutnya yaitu uji tingkat kesukaran soal guna mengetahui seberapa sukarnya soal (Arifin, 2018). Tahap uji yang terakhir, yaitu kemampuan antara butir soal dapat membedakan dengan peserta didik yang mahir dalam materi yang diuji kepada pebelajar dan pebelajar yang masih belum mahir materi yang diujikan tersebut (Fatimah, 2019).

Teknik menguji data dengan ANOVA (Analysis of Variance) karena teknik itu untuk mengetahui ada atau tidak adanya pengaruh dari berbagai patokan yang diujikan kepada hasil yang diharapkan. Tujuannya menggunakan teknik ini adalah guna membandingkan lebih dari dua rata-rata yang bertujuan guna menguji kemampuan generalisasi (Rahmawati, 2020). Analisis data digunakan dengan aplikasi pengolahan data, kemudian data itu dianalisa dengan metode statistika yaitu statistik deskriptif dan statistik inferensial parametrik. Pengujian hipotesis ini dilakukan dengan menggunakan ANOVA. Tahap selanjutnya dilakukan penghitungan uji T-test untuk mamastikan pengaruh antar variabel, sedangkan Ftest untuk memastikan pengaruh variabel bebas kepada variabel terikat.

\section{HASIL DAN PEMBAHASAN}

Pada bagian ini membahas mengenai hasil perolehan data di lapangan serta hasil pengolahannya. Penghitungan data yang diperoleh dan dikaitkan dengan variabel yang sudah ditentukan. Data penelitian disebarkan kepada 71 sampel penelitian. Metode kuesioner yang diperoleh melalui pebelajar yang mengisi kuisioner melalui Google Form (G-Form) untuk mengetahui variabel gaya siswa belajar 
sedangkan variabel hasil belajar siswa didapatkan melalui metode tes setelah siswa mengirimnya melalui G-Form. Angket memiliki tujuan guna mendapatkan fakta tentang gaya siswa belajar dari responden (Sulistyo-Basuki, 2006).

\section{Hasil Uji Validitas dan Reliabilitas}

Setelah melakukan post test kemudian menguji soal tes. Uji yang dilakukan adalah uji validitas soal tes. Hasil yang valid jika mempunyai nilai $r$ hitung lebih besar dari pada $r$ tabel. Dari 71 responden yang mengisi instrumen soal itu memiliki $r$ tabel berjumlah 0,2335 . Jadi, semua soalnya valid dan boleh diujikan kepada pebelajar. Dan hasil yang didapatkan pada uji reliabilitas diperoleh nilai 0,633 yang artinya data itu memiliki instrumen soal yang reliabel.

\section{Uji Tingkat Kesukaran Soal dan Daya Beda}

Berikut hasil uji tingkat kesukaran soal yang ditampilkan pada tabel 1.

Tabel 1. Uji Kesukaran Soal

\begin{tabular}{|c|c|c|c|c|c|c|c|c|c|c|c|}
\hline & & $\begin{array}{c}\text { SOAL } \\
1 \mathrm{~A} \\
\end{array}$ & $\begin{array}{c}\text { SOAL } \\
1 \mathrm{~B} \\
\end{array}$ & $\begin{array}{c}\text { SOAL } \\
2 \mathrm{~A} \\
\end{array}$ & $\begin{array}{c}\text { SOAL } \\
2 \mathrm{~B} \\
\end{array}$ & $\begin{array}{c}\text { SOAL } \\
3 \mathrm{~A} \\
\end{array}$ & $\begin{array}{c}\text { SOAL } \\
\text { 3B } \\
\end{array}$ & $\begin{array}{c}\text { SOAL } \\
4 \mathrm{~A} \\
\end{array}$ & $\begin{array}{c}\text { SOAL } \\
4 \mathrm{~B} \\
\end{array}$ & $\begin{array}{c}\text { SOAL } \\
5 \mathrm{~A} \\
\end{array}$ & $\begin{array}{c}\text { SOAL } \\
5 \mathrm{~B} \\
\end{array}$ \\
\hline \multirow[t]{2}{*}{$\mathrm{N}$} & Valid & 71 & 71 & 71 & 71 & 71 & 71 & 71 & 71 & 71 & 71 \\
\hline & Missing & - & - & - & - & - & - & - & - & - & - \\
\hline \multicolumn{2}{|c|}{ Mean } & 5.15 & 5.45 & 5.25 & 4.48 & 4.85 & 4.87 & 5.42 & 5.13 & 4.79 & 4.92 \\
\hline
\end{tabular}

Tabel 1 terdapat 10 soal. Dari 10 soal itu didapatkan hasil rata-rata diatas 0,31 yang mengindikasikan bahwa soal tersebut mempunyai tingkat kesulitannya sedang.

\section{Uji Daya Beda}

Berikut ini hasil daya beda yang ditampilkan pada tabel 2 .

Tabel 2. Daya Beda

\begin{tabular}{|c|c|c|c|c|c|c|c|c|c|c|c|}
\hline & & $\begin{array}{c}\text { Soal } \\
1 \mathrm{~A}\end{array}$ & $\begin{array}{c}\text { Soal } \\
1 \mathrm{~B}\end{array}$ & $\begin{array}{c}\text { Soal } \\
2 \mathrm{~A}\end{array}$ & $\begin{array}{c}\text { Soal } \\
2 \mathrm{~B}\end{array}$ & $\begin{array}{c}\text { Soal } \\
3 \mathrm{~A}\end{array}$ & $\begin{array}{c}\text { Soal } \\
3 \mathrm{~B}\end{array}$ & $\begin{array}{c}\text { Soal } \\
4 \mathrm{~A}\end{array}$ & $\begin{array}{c}\text { Soal } \\
4 \mathrm{~B}\end{array}$ & $\begin{array}{c}\text { Soal } \\
5 \mathrm{~A}\end{array}$ & $\begin{array}{c}\text { Soal } \\
5 \mathrm{~B} \\
\end{array}$ \\
\hline \multirow[t]{3}{*}{ TOTAL } & $\begin{array}{l}\text { Pearson } \\
\text { Correlation }\end{array}$ & $.256^{*}$ & $.336^{* *}$ & $.341^{* *}$ & $.251^{*}$ & $.277^{*}$ & $.279^{*}$ & $.278^{*}$ & $.270^{*}$ & $.467^{* * *}$ & $.392^{* *}$ \\
\hline & Sig. (2-tailed) & .031 & .004 & .004 & .034 & .019 & .018 & .019 & .023 & .000 & .001 \\
\hline & $\mathrm{N}$ & 71 & 71 & 71 & 71 & 71 & 71 & 71 & 71 & 71 & 71 \\
\hline
\end{tabular}

Pada tahap ini agar mengetahui daya beda soal bisa dilihat dari hasil validitas soal yang dilakukan sebelumnya. Soal diterima apabila soal memiliki tingkat Pearson Correlation diatas $\mathrm{r}_{\text {hitung }}$ atau sebesar 0,2335 . Berdasarkan hasil itu artinya semua soal dapat diterima.

\section{Hasil Angket Gaya Belajar Siswa}

Pada tahap ini dijabarkan hasil angket gaya belajar siswa yang telah dilakukan sebelumnya. Angket ini digunakan untuk mengelompokkan siswa sesuai dengan gaya belajarnya di masing-masing kelas. Berikut hasil angket gaya belajar yang dijabarkan dalam tabel 3 .

Tabel 3. Hasil Angket Gaya Belajar Siswa

\begin{tabular}{|l|l|l|}
\hline Kaya belajar & Kontrol & Eksperimen \\
\hline
\end{tabular}




\begin{tabular}{|c|c|c|}
\hline Visual & 12 & 16 \\
\hline Auditorial & 20 & 18 \\
\hline Kinestetik & 3 & 2 \\
\hline
\end{tabular}

Dari data yang diperoleh gaya siswa belajar pada kelas kontrol sebanyak 12 pebelajar, sedangkan pada kelas eksperimen sebanyak 16 pebelajar. Belajar dengan gaya auditorial pada kelas kontrol sebanyak 20 pebelajar, sedangkan pada kelas eksperimen sebanyak 18 pebelajar. Berikutnya pada belajar dengan gaya kinestetik diperoleh hasil pada kelas kontrol sebanyak 3 pebelajar, sedangkan pada kelas eksperimen sebanyak 2 pebelajar saja.

\section{Hasil Test Siswa}

Pada tahap ini dijabarkan hasil test siswa. Berikut hasil test siswa yang dijabarkan dalam tabel 4.

Tabel 4. Hasil Test Siswa

\begin{tabular}{|l|l|r|r|r|}
\hline \multicolumn{1}{|c|}{ Kelas } & Gaya belajar siswa & \multicolumn{1}{c|}{ Mean } & Std. deviation & \multicolumn{1}{c|}{ N } \\
\hline Kelas & Visual & 63.81 & 5.188 & 760 \\
& Auditorial & 63.24 & 7.657 & 1246 \\
& Kinestetik & 70.00 & .000 & 210 \\
& Total & 64.08 & 6.776 & 2216 \\
\hline Kelas & Visual & 77.47 & 3.555 & 1237 \\
Eksperimen & Auditorial & 76.89 & 2.879 & 1382 \\
& Kinestetik & 75.00 & .000 & 150 \\
& Total & 77.04 & 3.178 & 2769 \\
& Visual & 72.27 & 7.877 & 1997 \\
& Auditorial & 70.42 & 8.864 & 2628 \\
& Kinestetik & 72.08 & 2.468 & 360 \\
& Total & 71.28 & 8.218 & 4985 \\
\hline
\end{tabular}

Dari tabel 4 diperoleh hasil nilai rata-rata pebelajar dengan gaya visual memperoleh nilai 63.81, kemudian belajar dengan gaya auditorial memperoleh nilai 63.24 , kemudian belajar dengan gaya kinestetik memperoleh nilai 70.00, sehingga kelas kontrol mendapatkan nilai rata-rata sebesar 64.08. Sedangkan di kelas eksperimen didapatkan nilai rata-rata pebelajar dengan gaya visual sebesar 77.47, selanjutnya gaya auditorial memperoleh nilai 76.89 , kemudian belajar dengan gaya kinestetik memperoleh nilai sebesar 75.00, sehingga kelas eksperimen mendapatkan nilai rata-rata sebesar 77.04. Nilai rata-rata belajar dengan gaya visual nilai 72.27 , belajar dengan gaya auditorial 70.42 , belajar dengan gaya kinestetik 72.08, sehingga kelas kontrol dan kelas eksperimen rata-rata nilainya 71.28.

\section{Uji T}

Masing-masing variabel dites untuk mengetahui pengaruh antar variabel. Untuk uji parsial yang pertama adalah menguji Ha $\mathrm{H}_{1}$ yaitu variabel model pembelajaran GI dengan variabel hasil belajar. Dari data yang sudah diperoleh terdapat nilai signifikansi sebesar 0,00. Apabila data yang memiliki signifikansi $<0,05$ maka adanya pengaruh model pembelajaran GI dengan hasil belajar siswa atau $\mathrm{Ha}_{1}$ diterima

Uji parsial berikutnya adalah menguji $\mathrm{Ha}_{2}$ yaitu gaya siswa belajar berpengaruh kepada hasil belajar siswa. Pada tahap ini pengujian dibagi menjadi tiga bagian yakni menguji gaya belajar visual dengan gaya siswa belajar auditorial, gaya siswa belajar visual dengan gaya siswa belajar kinestetik, dan 
gaya siswa belajar auditorial dengan gaya siswa belajar kinestetik. Dari hasil perhitungan $t$-test dari ketiga pengujian tersebut diperoleh hasil signifikan 0,00 . Apabila data yang memiliki signifikan $<0,05$ maka adanya pengaruh gaya belajar terhadap hasil belajar siswa atau $\mathrm{Ha}_{2}$ diterima.

\section{Uji F}

Pada uji F dilakukan dua cara yaitu dengan mencari hasil r square dan ANOVA Two Way. Berikut ini dijabarkan hasil r square dan ANOVA Two Way yang dijabarkan dalam tabel 5.

Tabel 5. R Square

\begin{tabular}{|c|c|c|c|c|}
\hline \multirow[b]{2}{*}{ Model } & \multirow[b]{2}{*}{$\mathrm{R}$} & \multicolumn{2}{|r|}{-} & \multirow[b]{2}{*}{$\begin{array}{l}\text { Std. Error of } \\
\text { the Estimate }\end{array}$} \\
\hline & & R Square & $\begin{array}{l}\text { Adjusted R } \\
\text { Square }\end{array}$ & \\
\hline 1 & $.884^{\mathrm{a}}$ & .781 & .781 & 2.098 \\
\hline
\end{tabular}

Dari hasil perhitungan diperoleh $\mathrm{R}$ sebesar 0,844 sedangkan hasil $\mathrm{R}$ square diperoleh hasil 0,781 . Dari hasil perhitungan tersebut dapat diartikan bahwa variabel gaya siswa belajar dan model pembelajaran memiliki pengaruh yang besar kepada hasil belajar dengan $78 \%$ dan sisanya berdasarkan faktor lainnya. Berikut ini ditampilkan hasil daftar perhitungan menggunakan uji ANOVA Two Way pada tabel 6.

Tabel 6. Hasil ANOVA TWO WAY

\begin{tabular}{|l|r|r|r|r|l|}
\hline Source & $\begin{array}{c}\text { Type III Sum } \\
\text { of Squares }\end{array}$ & df & Mean Square & F & Sig. \\
\hline Corrected model & $216100.805^{\mathrm{a}}$ & 5 & 43220.161 & 1785.874 & .000 \\
Intercept & 12058016.66 & 1 & 12058016.66 & 498242.083 & .000 \\
JenisKelas & 69188.747 & 1 & 69188.747 & 2858.907 & .000 \\
Gaya & 1927.747 & 2 & 963.873 & 39.828 & .000 \\
JenisKelas*Gaya & 6073.424 & 2 & 3036.712 & 125.478 & .000 \\
Error & 120497.379 & 4979 & 24.201 & & \\
Total & 25664321.00 & 4985 & & & \\
Corrected Total & 336598.183 & 4984 & & & \\
\hline
\end{tabular}

Analisis data berikutnya yaitu ANOVA Two Way dengan memperoleh nilai rata-rata corrected model sebesar 43220.161, kemudian df 5 dan F sebesar 1785.847 dengan signifikansi sebesar 0.00 , berikutnya intercept memperoleh nilai rata-rata 12058016.66, kemudian df 1 dan F sebesar 498242.083 dengan signifikansi 0.00. Berikutnya jenis kelas memperoleh nilai rata-rata 69188.747, kemudian df 1 dan F sebesar 2858.907 dengan signifikansi sebesar 0.00. Berikutnya gaya memperoleh nilai rata-rata 963.873, kemudian df 2 dan F sebesar 39.828 dengan signifikansi sebesar 0.00. Berikutnya JenisKelas*Gaya memperoleh nilai rata-rata 3036.712, kemudian df 2 dan F sebesar 125.487 dengan signifikansi sebesar 0.00. Dari data diperoleh menunjukkan bahwa variabel model pembelajaran dan gaya belajar memiliki pengaruh terhadap gaya siswa belajar. Sehingga dalam penelitian ini $\mathrm{Ha}_{3}$ diterima dan $\mathrm{H}_{0}$ ditolak.

Untuk mengetahui seberapa besar pengaruh model GI ini kepada hasil belajar siswa, maka diperlukan pengujian parsial atau uji T. Dalam hasil uji T ini diketahui bahwa data diatas memperoleh signifikan 0,00. Dari tabel 4 tentang hasil test siswa terlihat kelas kontrol nilai rata-ratanya 64.08 sedangkan kelas eksperimen nilai rata-ratanya 77.04. Nilai rata-rata pebelajar yang berada di kelas eksperimen berhasil mendapatkan nilai diatas nilai standar yakni 75, tidak seperti kelas kontrol yang rata-rata pebelajar masih mendapatkan nilai kurang dari 75 yang berarti nilai pebelajar masih dibawah standar. Dari hasil tersebut pebelajar pada kelas eksperimen mendapatkan nilai lebih tinggi daripada kelas kontrol dikarenakan adanya perlakuan. 
Hal ini sejalan dengan Widiawati (2018) dalam penelitiannya bahwa hasil belajarnya pebelajar pada kelas yang diberikan perlakuan model GI mempunyai hasil yang lebih baik dari kelas yang tidak diberikan perlakuan. Hal itu bisa dilihat dengan perolehan nilai tes akhir rata-rata pebelajar yang mendapat perlakuan GI mendapatkan nilai sebesar 74,1 sedangkan kelas yang tidak diberi perlakuan GI mendapatkan nilai sebesar 65,4. Penelitian ini juga didukung oleh penelitian Rahmatullah, et al (2017) menyimpulkan bahwa model pembelajaran GI dapat berpengaruh terhadap aktivitas dan hasil belajarnya.

Untuk mengetahui seberapa besar pengaruh gaya siswa belajar terhadap hasil belajarnya kemudian dilakukan uji parsial atau uji T. Hasilnya diketahui bahwa nilai signifikannya sebesar 0,00 . Apabila data yang signifikannya kurang dari 0,05 maka terdapat pengaruh gaya belajar terhadap hasil belajarnya atau $\mathrm{Ha}_{2}$ diterima. Uji ini dilakukan dengan cara membandingkan hasil nilai tes pebelajar dikedua kelas dengan cara menggelompokkan nilai berdasarkan gaya siswa belajar yang sudah dilakukan tes terlebih dahulu. Hasilnya bisa dilihat di tabel 4 tentang hasil tes pebelajar. Di tabel itu disebutkan nilai belajar siswa dengan gaya secara visual pada kelas tanpa perlakuan model GI mendapatkan nilai sebesar 63.81 sedangkan pada kelas eksperimen sebesar 77.47. Belajar dengan gaya auditorial pada kelas kontrol mendapatkan nilai sebesar 63.24 sedangkan pada kelas perlakuan model GI mendapatkan nilai sebesar 76.89. Untuk gaya siswa belajar secara kinestetik pada kelas tanpa perlakuan GI mendapatkan nilai sebesar 70.00 dan di kelas perlakuan model GI senilai 75.00.

Dari data diatas nilai rata-rata berdasarkan gaya siswa belajar berpengaruh terhadap hasil belajar. Hal tersebut serupa dengan Halim (2012) bahwa ada perbedaan hasil dalam belajar yang condong pada gaya siswa belajar. Namun hal ini juga ada kesamaan dengan Widiawati (2018) yang serupa membuktikan bahwa ada perbedaan hasil dalam belajar yang memiliki kecenderungan pada gayanya dalam belajar. Walaupun kedua kelas mendapatkan perlakuan berbeda pada kedua kelas namun, pebelajar dengan cara gaya visual mendapatkan nilai lebih tinggi ketimbang gaya belajar lainnya.

Untuk mengetahui seberapa besar pengaruh model pembelajaran GI kepada hasil belajar siswa kemudian dilakukan uji simultan atau uji F. dalam hasil uji $\mathrm{F}$ ini diketahui bahwa $\mathrm{F}_{\text {hitung }}$ sebesar 3,740 dan nilai $F_{\text {tabel }}$ sebesar 3,14. Dari kedua nilai tersebut diketahui bahwa $F_{\text {hitung }}>F_{\text {tabel }}$ sehingga dapat dinyatakan model pembelajaran GI dengan gaya belajar memiliki pengaruh kepada hasil siswa dalam belajar. Dalam penelitian ini $\mathrm{Ha}_{1}$ diterima dan $\mathrm{Ha}_{0}$ ditolak.

Penelitian ini dikuatkan dengan dilakukannya uji korelasi atau hubungan. Dalam hasil uji dinyatakan bahwa nilai $\mathrm{R}$ sebesar 0,844 . Sehingga apabila dicocokkan menggunakan pedoman derajat hubungan, maka hasilnya adalah variabel bebas dan variabel terikat dalam penelitian ini memiliki hubungan korelasi kuat.

Tabel 3 tentang hasil angket gaya siswa dalam belajar menunjukkan bahwa pebelajar di kelas kontrol maupun eksperimen didominasi oleh pebelajar dengan gaya auditorial dengan masing masing berjumlah 20 dan 18 pebelajar. Kemudian untuk gaya belajar lain diikuti oleh gaya visual serta kinestetik. Pebelajar dengan gaya kinestetik memiliki jumlah paling sedikit sebanyak 3 di kelas kontrol dan 2 di kelas eksperimen sedangkan untuk belajar dengan gaya visual kelas kontrol memiliki 12 pebelajar dan kelas eksperimen memiliki 16 pebelajar. Tabel 4 juga menunjukkan hasil nilai rata-rata pebelajar berdasarkan gaya belajarnya. Hasil ini menunjukkan bahwa rata-rata nilai pebelajar dengan gaya visual lebih tinggi dari pebelajar dengan gaya kinestetik, sedangkan rata-rata nilai gaya kinestetik lebih tinggi dari gaya auditorial. Hal ini menunjukkan bahwa pemberian perlakuan lebih baik dibandingkan dengan tanpa perlakuan model GI.

Penelitian ini juga didukung dengan hasil penelitiannya Widiawati (2018) memaparkan beberapa hal yang bisa berpengaruh pada hasil belajar fisika yakni model GI itu sendiri dan juga gaya siswa belajar. Hasil penelitian itu menunjukkan adanya interaksi antara strategi dan gaya siswa belajar yang bisa mempengaruhi hasil belajar. Selain itu juga penelitian ini didukung oleh 'Ardhuha, et al. (2016) 
yang menyimpulkan bahwa terdapat pengaruh interaksi sebesar 50,2 persen antara model GI dengan gaya siswa belajar terhadap hasil belajar IPA Fisika.

\section{SIMPULAN}

Model pembelajaran GI berdasarkan pengujian yang telah dilakukan pada mata pelajaran geografi materi kebudayaan kelas XI IPS mampu memberikan hasil belajar siswa yang positif. Hal tersebut dibuktikan pada penelitian kali ini yang bertujuan untuk membuktikan hipotesis yang ada. Pada hipotesis yang pertama yakni adanya pengaruh model pembelajaran GI kepada hasil belajarnya. Dari hipotesis yang ada dibuktikan bahwa ada pengaruh model tersebut kepada hasil belajarnya yang dibuktikan pada adanya perubahan hasil belajar pada kelas kontrol dan kelas eksperimen. Hipotesis yang kedua yakni adanya pengaruh gaya siswa belajar kepada hasil belajar. Dari hipotesis tersebut dibuktikan bahwa adanya pengaruh gaya belajarnya siswa kepada hasil belajar yang dibuktikan pada ada perbedaan hasil belajar siswa pada ketiga kategori gaya siswa belajar.

\section{DAFTAR RUJUKAN}

Ahrisya, L. (2019). Pengaruh Model Pembelajaran Contextual Teaching and Learning (CTL) Terhadap Hasil Belajar Siswa Kelas V Sekolah Dasar. JKTP. 2 (4): 306-314

'Ardhuha, J., dan Nurmayani, Syuaib, M. Z. (2016). Pengaruh Gaya Belajar VAK pada Penerapan Model Pembelajaran Problem Based Learning Terhadap Hasil Belajar IPA Fisika Siswa SMP Negeri 2 Narmada Tahun Ajaran 2015/2016. Jurnal Pendidikan Fisika dan Teknologi. 2 (1): 1321.

Arifin dan Afandi. (2015). Pengaruh Pembelajaran Kooperatif Tipe Investigasi Kelompok (Group Investigation) dan Strategi Student Team Achievement Division (STAD) terhadap Keterampilan Proses dan Hasil Belajar Akuntansi Siswa SMK di Kota Kediri. Nusantara of Research. 2 (1): 1025.

Arifin, I. (2018). Pengembangan Soal-Soal Pilihan Ganda untuk Mengukur Kemampuan Berpikir Kritis Siswa pada Konsep Sistem Regulasi Manusia untuk Jenjang SMA. Mangifera Edu 3 (1): 26-39.

Bobby De Porter dan Mike Hemacki. (2011). Quantum Learning Nyaman dan Menyenangkan. Bandung: Kaifa.

Degeng, I. N. S. (1989). Desain Pembelajaran: Teori dan Praktik. IKIP Malang: Penyelenggaraan Pendidikan Pascasarjana Proyek Peningkatan Perguruan Tinggi IKIP Malang.

Fatimah L. U. (2019). Analisis Kesukaran Soal, Daya Pembeda, dan Fungsi Distraktor. Al-Manar. 8 (2): $37-64$

Faujiyah C. R. (2017). Penerapan Model Pembelajaran Group Investigation terhadap Hasil Belajar Siswa pada Materi Sistem Ekskresi Manusia. Jurnal Program Studi Pendidikan Biologi. 7 (1):112.

Felder, R. M. 1996. Matters of Style. Raleigh: Asee Prims, 6 (4): 115-126.

Gunada, I. W., dan Sahidu, H., Sutrio, S. (2015). Pengembangan Perangkat Pembelajaran Fisika Berbasis Masalah untuk Meningkatkan Hasil Belajar dan Sikap Ilmiah Mahasiswa. Jurnal Pendidikan dan Teknologi. 1 (1): 38-46.

Gunawan, G., Sahidu, H., Harjono, A., \& Suranti, N. M. Y (2017). The Effect of Project Based Learning with Virtual Media Assistance on Student's Creativity in Physics. Cakrawala Pendidikan, (2), 167179.

Halim, A. (2012). Pengaruh Strategi Pembelajaran dan Gaya Belajar terhadap Hasil Belajar Fisika Siswa SMPN 2 Secanggang Kabupaten Langkat. Jurnal Tabularasa PPS Unimed. 9 (2): 141-158. 
Maryani, M., \& Rahayu, T. S. (2019). Peningkatan Hasil Belajar Matematika melaluiModel Group Investigation dengan Media Games Puzzle pada Kelas V Sekolah Dasar. Jurnal Basicedu. 3(1), $60-65$.

Oktaviani, E. (2018). Pengaruh Group Investigation terhadap Hasil Belajar Fisika Peserta Didik pada Pokok Bahasan Gerak Lurus Kelas X Di SMAN 1 Jabung Lampung Timur. Indonesian Journal of Science and Mathematics Education.1 (2): 23-28.

Oktaviansa, W. A., \& Yunus, Y. (2013). Pengaruh Model Pembelajaran CTL (Contextual Teaching and Learning) Terhadap Motivasi Dan Hasil Belajar Siswa SMKN 1 Sidoarjo. Jurnal Pendidikan Teknik Mesin. 2(01): 34-43.

Pujani, M, dan Restami, M. P, Suma, K. 2013. Pengaruh Model Pembelajaran POE (Predict-ObserveExplain) terhadap Pemahaman Konsep Fisika dan Sikap Ilmiah Ditinjau dari Gaya Belajar Siswa. E-Journal Program Pascasarjana Universitas Pendidikan Ganesha Program studi IPA. Vol 3: 111 .

Purwanto. (2005). Tujuan Pendidikan dan hasil Belajar: Domain dan Taksonomi. Jurnal Teknodik. 9 (16): 146-164.

Rahmatullah, Sahidu, H., Ayub, S. 2017. Pengaruh Model Pembelajaran Kooperatif Tipe Group Investigation (GI) dengan Teknik Open-Ended Problem Terhadap Aktivitas dan Hasil Belajar Fisika Siswa SMAN 3 Mataram. Jurnal Pendidikan Fisika dan Teknologi. 3 (2): 109-118.

Rahmawati, A. S. dan Erina R. (2020). Rancangan Acak Lengkap (RAL) dengan Uji Anova Dua Jalur. Optika. 4 (1): 54-62

Rosita, Leonard. (2015). Meningkatkan Kerja Sama Siswa melalui Pembelajaran Kooperatif Tipe Think Pair Share. Jurnal Formatif: 3 (1): 1-10.

Sari, N.M, dan Eurika N. (2016). Penerapan Model Pembelajaran Group Investigation untuk Meningkatkan Hasil Belajar Siswa Apllication of Group Investigation Learning Model To Improve Student Learning Outcome. Jurnal Biologi dan Pembelajaran Biologi. 1 (1): 29-41.

Slavin, R. E. (2010). Cooperative Learning Teori, Riset dan Praktik. Bandung: Nusa Media.

Sugiyono, (2001). Metode Penelitian. Bandung: CV Alfa Beta.

Sulistyo-Basuki. (2006). Metode Penelitian. Jakarta: Wedatama Widya Sastra dan Fakultas Ilmu Pengetahuan Budaya Universitas Indonesia.

Suparmi, dan Susilo, F., Sunarno, W. (2016). Pembelajaran Fisika Menggunakan Model jigsaw dan GI Ditinjau dari Kreativitas dan Sikap Ilmiah Belajar Siswa. Jurnal Inkuiri. 5 (3): 40-48.

Sternberg, R. J. 1994. 'Allowing for thinking styles'. Educational Leadership 52/3: 36-40.

Wahyuni, R., dan Hikmawati, Taufik, M. (2016). Pengaruh Model Pembelajaran Inkuiri Terbimbing dengan Metode Eksperimen terhadap Hasil Belajar Fisika Siswa Kelas XI IPA SMAN 2 Mataram Tahun Pelajaran 2016/2017. Jurnal Pendidikan Fisika dan Teknologi. 2 (4): 164-169.

Wicaksono, B. (2017). Model Pembelajaran Group Investigation dan Think Pair Share terhadap Kemampuan Berpikir Kritis. Aksioma. 8 (2): 1-8.

Widiawati, S. (2018). Pengaruh Model Pembelajaran Kooperatif Tipe Group Investigation (GI) Terhadap Hasil Belajar Fisika Ditinjau dari Gaya Belajar Siswa. Jurnal pendidikan Fisika dan Biologi, Universitas Mataram. 4 (1): 40-48.

Zakiyatun, C. Pengaruh Media Peta Konsep Dalam Model Pembelajaran Kooperatif Tipe Numbered Heads Together (NHT) terhadap Hasil Belajar dan Daya Ingat Siswa pada Materi Hidrolisis Garam Kelas XI MIPA SMA Negeri 7 Pontianak. Ar-Razi Jurnal Ilmiah. 5 (2): 159-168. 
